\title{
The Action of Bovine Cartilage on Tumor Cells In Vitro And In Vivo
}

\author{
Arax Tanelian and Alexander M. Abdelnoor \\ Department of Experimental Pathology, Immunology and Microbiology, \\ Faculty of Medicine, American University of Beirut, Lebanon
}

\author{
Article history \\ Received: 08-12-2017 \\ Revised: $12-12-2017$ \\ Accepted: 19-01-2018 \\ Corresponding Author: \\ Dr. Alexander M. Abdelnoor \\ Department of Experimental \\ Pathology, Immunology and \\ Microbiology, Faculty of \\ Medicine, American University \\ of Beirut, P.O. Box 11-0236, \\ Riad El-Solh / Beirut 1107 \\ 2020, Beirut, Lebanon. \\ Tel: (+)961 1350000 \\ Fax: (+)961 1744487 \\ Email: aanoor@aub.edu.lb
}

\begin{abstract}
In an earlier study we had investigated the effect of Bovine Cartilage (BC) on mouse melanoma cells. In pursuant to this study BC antitumor activity in vitro against several human tumor cell lines was evaluated, mechanism by which BC induces tumor cell death was studied and its immunogenicity was assessed. Five mice received Intraperitoneal (IP) injection of BC once every 14 days for over a period of 42 days. Fourteen days after the last $\mathrm{BC}$ dose, mice were bled and sera were used to assess production of anti-BC antibodies by passive hemagglutination. To assess the effect of BC on human tumor cells, three different human tumor cell lines were incubated separately with increasing concentrations of $\mathrm{BC}$ for $48 \mathrm{~h}$ and percent viability was determined in vitro. Moreover, human lung cancer cell line A549 and mouse B16F10 melanoma cells were incubated separately with their respective half maximal inhibitory concentration (IC50) of BC and apoptosis/necrosis assay was performed. No antibody against $\mathrm{BC}$ was detected. In vitro, total eradication of human tumor cell lines was seen with $5000 \mu \mathrm{g} \mathrm{mL} L^{-1}$ of BC. It appears that $\mathrm{BC}$ induces tumor cell death through apoptosis and this mechanism of action is the same across different cell lines and species. Additionally, BC appeared to be non-immunogenic.
\end{abstract}

Keywords: Bovine Cartilage, MDA-MB-231, A549, PC3

\section{Introduction}

It has been reported that Bovine Cartilage (BC) has several useful medical properties including acceleration of wound healing, an anti- inflammatory property and an anti-tumor activity.

John F. Prudden was the first to assess the ability of Bovine Cartilage to accelerate healing in experimental wounds as well as in chronically non healing human wounds (Prudden et al., 1975; Takayuki, 1960; Prudden et al., 1962; 1964; Prudden, 1964; Prudden and Allen, 1965). Subsequently, a study conducted by Houck et al. (1961) showed that, in addition to having ability in wound healing, BC presents a potent antiinflammatory activity. This anti-inflammatory ability of $\mathrm{BC}$ further triggered Prudden to assess its role in treating cancer (Prudden, 1985). For this purpose 31 terminally ill patients, each with a different type of malignancy, were subjected to BC treatment; Prudden registered some significant improvements in a wide variety of intractable malignancies (Prudden, 1985).
The mechanism of action underlying the anti-tumor activity of $\mathrm{BC}$ is not well defined. At least four possible mechanisms have been proposed; $\mathrm{BC}$ might directly induce cancer cell death (Prudden, 1985; Durie et al., 1985), it could stimulate the immune system (Rosen et al., 1998; Morell and Daniel, 2014), it might inhibit collagenase activity (Kuettner et al., 1977; Murray et al., 1986) and/or it could inhibit angiogenesis (Folkman et al., 1971; Langer et al., 1976).

The use of $\mathrm{BC}$ to accelerate wound healing and treat inflammatory diseases has been adopted by the physicians in medical fields, but its anti-tumor activity was not further investigated.

Earlier, we investigated the effect of $\mathrm{BC}$ on the survival of B16F10 melanoma cells and mouse mononuclear cells (Tanelian et al., 2016). The aim of this study was to further evaluate the in vitro anti-tumor activity of $\mathrm{BC}$ against human tumor cell lines, determine the mode by which it induces tumor cell death and assess its immunogenicity. 


\section{Materials and Methods}

\section{In Vitro Evaluation of BC Effect}

BC used was "NOW Bovine Cartilage" (395 S. Glen Elyn Rd, Bloomingdale, IL), a commercially available extract. The powdered $\mathrm{BC}$ was weighed, dissolved in sterile distilled water and stored at $-20^{\circ} \mathrm{C}$ until used.

\section{Cell Lines and Culture Conditions}

MDA-MB-231 breast cancer cell line, A549 human lung carcinoma cell line and PC3 human prostate adenocarcinoma cell line were generously provided by Dr. Marwan El-Sabban from the department of Anatomy, Cell Biology and Physiology at the American University of Beirut. MDA-MB-231 cells were cultured in RPMI-1640, supplemented with $10 \%$ Fetal Bovine Serum (FBS) and 1\% PenStrep, whereas A549 and PC3 cells were cultured in a medium containing RPMI-1640, 10\% FBS, 1\% L-Glut and $1 \%$ Pen-Strep. All cells were incubated at $37^{\circ} \mathrm{C}$ in a humidified incubator with $5 \% \mathrm{CO}_{2}$.

\section{Proliferation Assays}

MDA-MB-231, A549 and PC3 cells were grown at $80 \%$ confluency, trypsinized, counted and seeded in 24well plates at a seeding density of $2 \times 10^{4}$ cells $/ 500 \mu \mathrm{l} / \mathrm{well}$, $1.8 \times 10^{4} \mathrm{cells} / 500 \mu \mathrm{l} / \mathrm{well}$ and $1.7 \times 10^{4}$ cells $/ 500 \mu \mathrm{l} / \mathrm{well}$ respectively. Cells were then incubated for $24 \mathrm{~h}$ prior to treatment by $500 \mu \mathrm{L}$ of five different $\mathrm{BC}$ concentrations $\left(5,10,100,1000\right.$ and $\left.5000 \mu \mathrm{g} \mathrm{mL}{ }^{-1}\right)$ for $48 \mathrm{~h}$. No BC was added to the control wells and the samples were run in duplicates. After $48 \mathrm{~h}$ of incubation the cells were collected and a viable cell count was determined with a haemocytometer using the trypan-blue exclusion assay.

\section{Determination of Apoptosis}

Apoptosis was detected in B16F10 melanoma and A549 cells using the ApoDETECT Annexin V-FITC Kit, following the manufacturer's protocol. Briefly, cells were seeded in 24-well plates with their respective growth medium at $2 \times 10^{4}$ cells/well and $1.8 \times 10^{4}$ cells/well respectively. The cells were treated with their respective IC50 of BC (IC50 ${ }_{\mathrm{A} 549}=189 \mu \mathrm{g} \mathrm{mL}-1$ and IC50 ${ }_{\mathrm{B} 16 \mathrm{~F} 10}=$ $167 \mu \mathrm{g} \mathrm{mL}^{-1}$ ) for $48 \mathrm{~h}$, collected by centrifugation and washed with ice cold PBS. The cells were then resuspended in $1 \mathrm{X}$ binding buffer at a cell density of 2$5 \times 10^{5}$ cells $/ \mathrm{mL}$. Ten microliters of Annexin V-FITC were added to $190 \mu \mathrm{L}$ of cell suspension and incubated for $10 \mathrm{~min}$ at room temperature. Finally, the cells were washed and PI was added on the re-suspended cells in $190 \mu \mathrm{L}$ binding buffer and analyzed by flow cytometry.

\section{In Vivo Study}

\section{Immunogenicity Assessment of Bovine Cartilage}

The use of mice in this study was approved by the Institutional Animal Care and Use Committee (IACUC) at the faculty of Medicine, American University of Beirut. Ten C57BL/6 female mice, 6 to 8 weeks old, were divided in to two groups (5 mice in each). One group remained untreated, while the second group received IP injection of $75 \mathrm{mg} \mathrm{mL}{ }^{-1}$ of $\mathrm{BC}$ at a dose of $0.4 \mathrm{ml} /$ mouse. The treatment was given once every 14 days for 42 days.

On day 56, 14 days after the last injection, all mice were anesthetized, dissected and blood was collected by cardiac puncture. Blood from each group was pooled and serum was separated and used for immunogenicity assessment by passive Hemagglutination using two different methods: Neter's method (Neter et al., 1956) and Boyden's Method (Boyden, 1951).

\section{Statistical Analysis}

Whenever applicable, data were expressed as a Mean $\pm \mathrm{SD}$. The IC50 of BC was calculated using GraphPad Prism 5.0. The unpaired student's T-test was performed for Statistical comparisons using Graph pad online software. Results were considered to be statistically significant at $\mathrm{P}$ value $<0.05$.

\section{Results}

\section{In Vitro Results}

\section{Viability of Human Tumor Cells Incubated with BCs}

The anti-tumor activity of $\mathrm{BC}$ was assessed, after exposing human tumor cells, MDA-MB-231, A549 and PC 3 cells, to increasing range of $\mathrm{BC}$ concentrations. After $48 \mathrm{~h}$ of incubation, similar anti-tumor response was seen against the three human tumor cells. Significant decrease in the viable MDA-MB-231, A549 and PC3 cell count was obtained in the wells treated with $500 \mu \mathrm{L}$ of $5 \mu \mathrm{g} \mathrm{mL}^{-1}(\mathrm{P}$ value $_{\mathrm{MDA} A \mathrm{MB} 231}=0.003, \mathrm{P}_{\text {value }}{ }_{\mathrm{A} 549}=0.0012, \mathrm{P}^{-1}$ value ${ }_{\mathrm{PC} 3}$ $=0), 10 \mu \mathrm{g} \mathrm{mL}^{-1}\left(\mathrm{P}_{\text {value }} \mathrm{MDA}-\mathrm{MB} 231=0.005, \mathrm{P}_{\text {value }}{ }_{\mathrm{A} 549}=\right.$ $\left.0.0001, \mathrm{P}_{\text {value }} \mathrm{PC}=0.0121\right), 100 \mu \mathrm{g} \mathrm{mL}^{-1}\left(\mathrm{P}\right.$ value $_{\mathrm{MDA}-\mathrm{MB}}$ ${ }_{231}=0.0013, \mathrm{P}_{\text {value }} \mathrm{A} 549=0.0014, \mathrm{P}$ value $\left.\mathrm{PC}=0.0059\right)$ and $1000 \mu \mathrm{g} \mathrm{mL}^{-1}\left(\mathrm{P}_{\text {value }} \mathrm{MDA}_{\mathrm{MB}-231}=0.001, \mathrm{P}\right.$ value ${ }_{\mathrm{A} 549}$ $=0.001, \mathrm{P}$ value $\left.\mathrm{PC}_{\mathrm{PC}}=0.0014\right)$ of $\mathrm{BC}$, when compared to their respective control wells. Total eradication of MDAMB-231, A549 and PC3 cells was obtained in the wells treated with $500 \mu \mathrm{L}$ of $5000 \mu \mathrm{g} \mathrm{mL}{ }^{-1}$ of BC (Fig. 1).

\section{Determination of Apoptosis and Necrosis using Flow Cytometry}

To determine the mode of tumor cell death, untreated and BC-treated B16f10 melanoma and A549 lung carcinoma cells were stained with annexin $\mathrm{V}$ and 
PI. Flow cytometry analysis of stained cells can differentiate cells into four groups, namely viable (annexin V-PI-), early apoptosis (annexin V+ PI-), late apoptosis (annexin $\mathrm{V}+\mathrm{PI}+$ ) and necrotic (annexin $\mathrm{V}$ $\mathrm{PI}+$ ) cells. As shown in Fig. 2 and 3, after $48 \mathrm{~h}$ of BC exposure, the majority of B16F10 melanoma and A549 lung carcinoma cells showed early and late apoptotic characteristics compared to their respective controls, where early apoptosis was the dominant feature in both tumor cell population. Moreover, the flow cytometry results revealed no significant difference between the percentages of necrotic cells for each BC-treated cell and their respective controls. Less than $2 \%$ of the $\mathrm{BC}$ treated population showed necrotic signs.

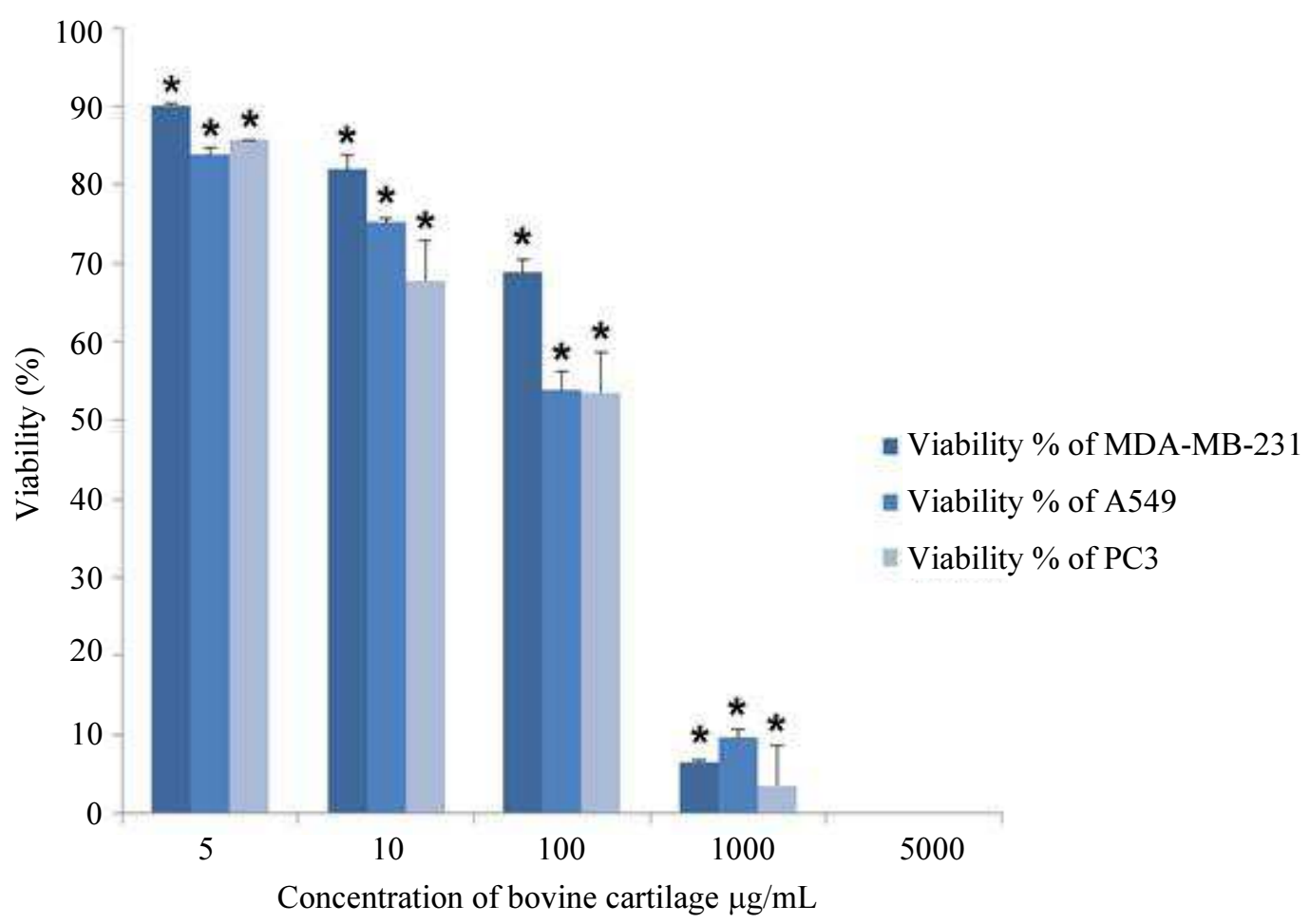

Fig. 1: Assessing the effect of BC on the growth of MDA-MB-231, A549, and PC3 cells in vitro. The viability of human tumor cells significantly decreased with increasing concentration of $\mathrm{BC}$, reaching a total eradication of cells at $5000 \mu \mathrm{g} \mathrm{mL}^{*}$ : Statistically significant at $\mathrm{p}$-value $<0.05$
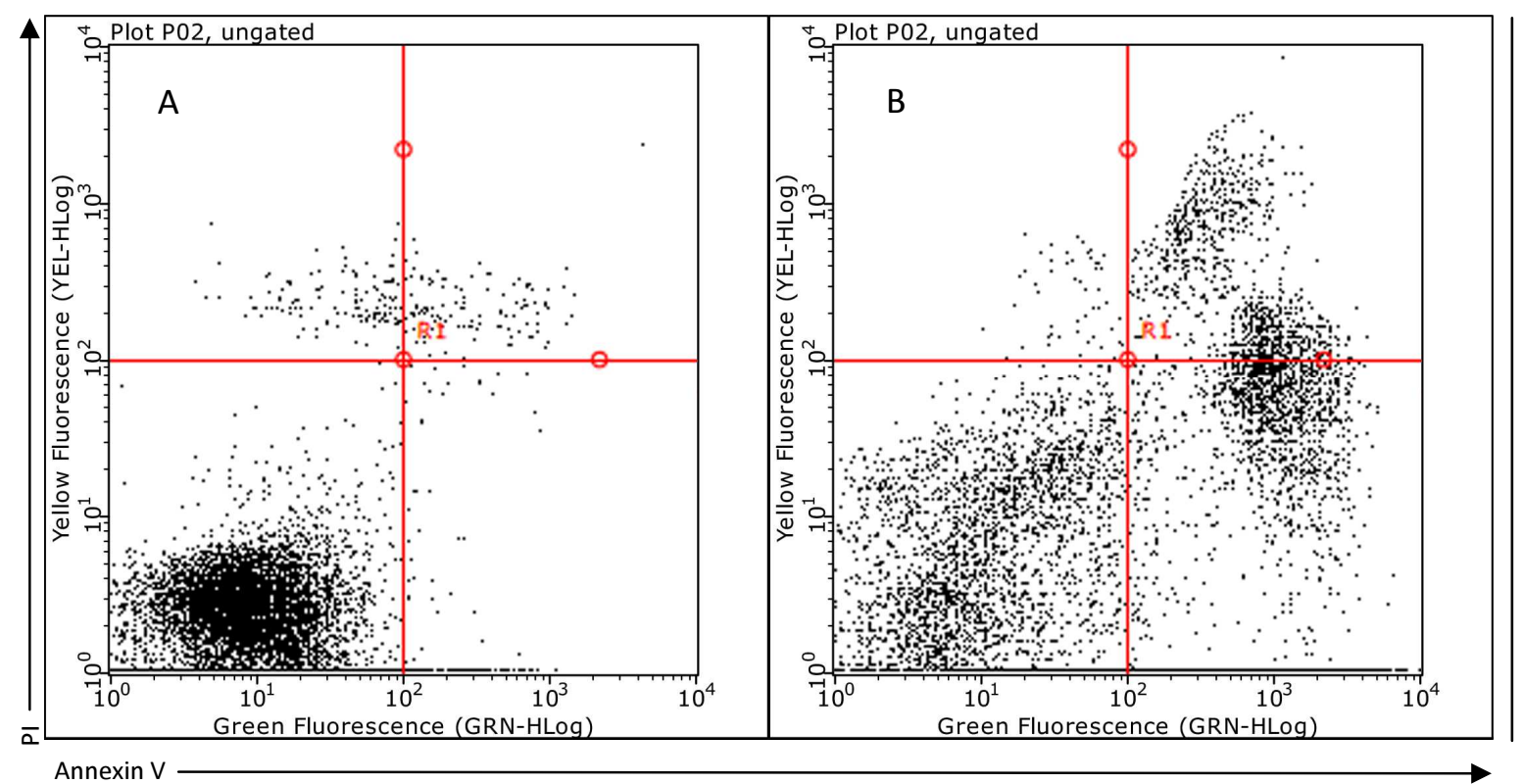

0
0
0
0
3
$\frac{1}{0}$
0
0
0
0
0
0
0

Annexin V 


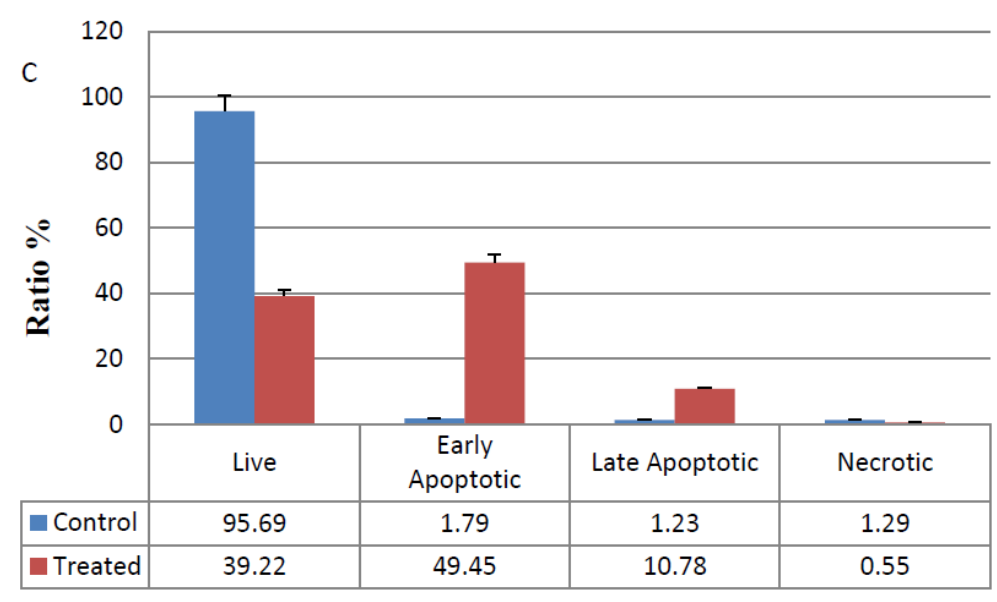

Fig. 2: BC-treated B16F10 Melanoma cells and their respective controls were stained by Annexin-V-FITC and Propidium Iodide (PI) and analyzed by flow cytometry. (A) Represents the B16F10 melanoma cells before BC treatment and acts as a control. (B) Represents B16F10 melanoma cells after BC treatment. (C) Bar chart comparing the ratio \% between untreated and BCtreated B16F10 melanoma cells
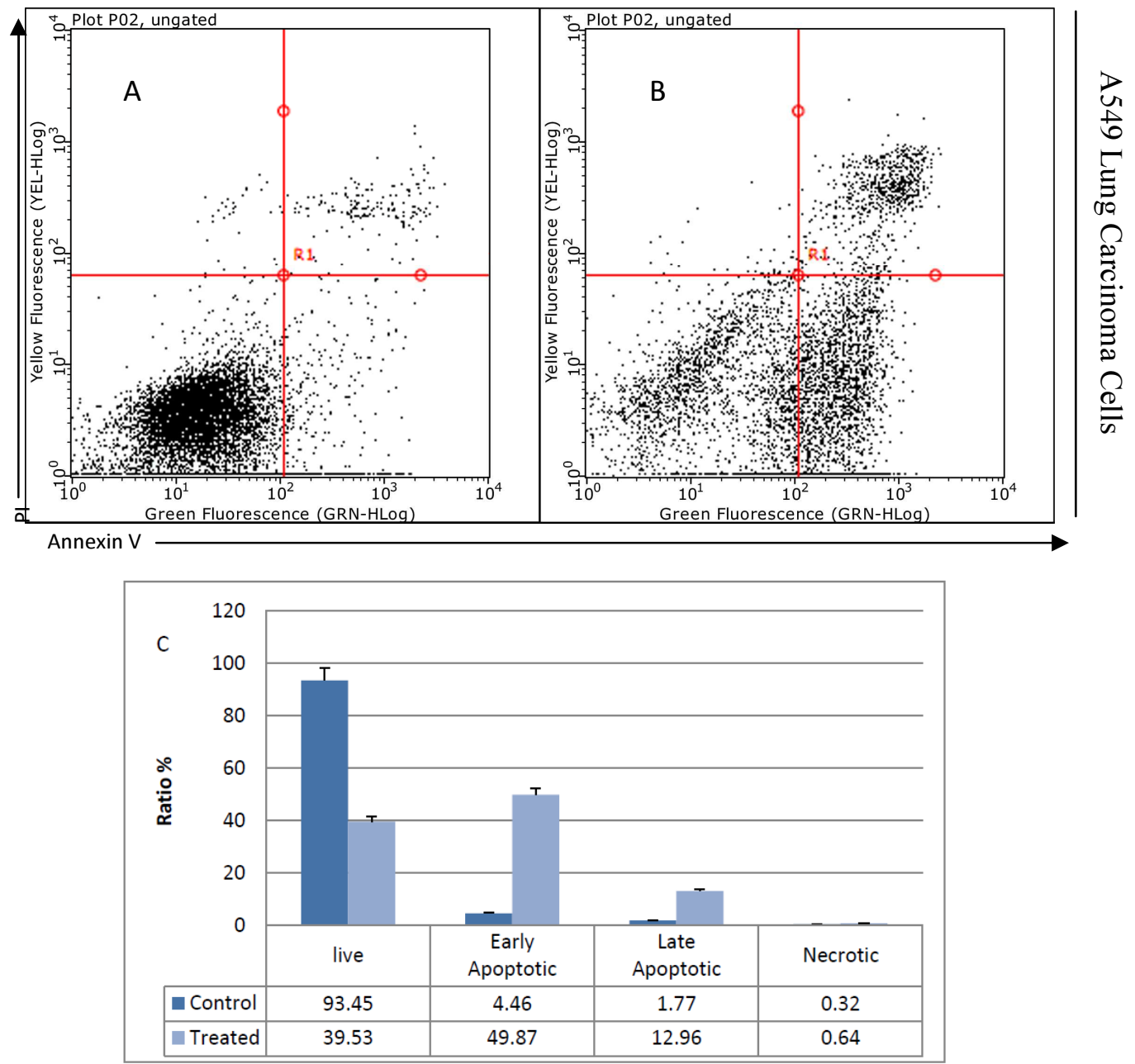

Fig. 3: BC-treated A549 human lung carcinoma cells and their respective controls were stained by annexin-V-FITC and Propidium Iodide (PI) and analyzed by flow cytometry. (A) Represents the A549 lung carcinoma cells before BC treatment and acts as a control. (B) Represents A549 lung carcinoma cells after BC treatment. (C) Bar chart comparing the ratio \% between the ntreated and BC-treated A549 lung carcinoma cells. 


\section{In Vivo Results}

\section{Immune Response after BC Treatment}

Neter et al. (1956) reported a passive hemagglutination method directed against polysaccharides found in a molecule and Boyden (1951) reported a passive hemagglutination directed against proteins found in a molecule. Using both Neter's and Boyden's method of passive hemagglutination, when compared to the normal serum control tube, BC- treated mice sera failed to cause agglutination of the sensitized erythrocytes in all the serially diluted tubes (1:10-1:20480) as it was indicated by the absence of diffused film at the bottom of the tubes.

\section{Discussion}

Prudden's systematic analysis of Bovine Cartilage's anti-inflammatory activity paved the way to discover different mechanisms by which BC acts on tumor cells. In our pervious study we investigated some of its mechanisms of action against cancer cells (Tanelian et al., 2016). The aim of this study was to evaluate the in vitro anti-tumor activity of $\mathrm{BC}$, determine its mode of action on tumor cells and assess its immunogenicity.

Previously, we showed that $\mathrm{BC}$ has direct anti-tumor activity against mouse B16F10 melanoma cells (Tanelian et al., 2016). To further underscore this direct anti-tumor effect, three different human tumor cells MDA-MB-231, A549 and PC3 cells were incubated separately with increasing concentrations of $\mathrm{BC}$ for $48 \mathrm{~h}$. In all three human tumor cells, significant dosedependent decrease in their viability was noted, reaching a total eradication of tumor cells at $5000 \mu \mathrm{g} \mathrm{mL}{ }^{-1}$ of BC. These results were consistent with our pervious outcome and with Durie et al. (1985) who, using the same BC concentrations demonstrated the anti-proliferative activity of $\mathrm{BC}$ against several human tumor cell lines.

In an attempt to identify the mode by which BC exerts its direct anti-tumor effect on tumor cells, two different tumor cells, the mouse B16F10 melanoma cells and the human A549 lung carcinoma cells were exposed to BC treatment for $48 \mathrm{~h}$. The flow cytometry results indicated that both BC-treated tumor cell types underwent apoptosis. The obtained results imply that the anti-tumor activity of BC is not restricted to a certain cell type and is the same across different species. In a similar study Prudden (1964) concluded that the effect of repair stimulating factor found in cartilage is not species specific.

Finally, in our previous study (Tanelian et al., 2016), we showed that, as Prudden stated, BC has an important role as a biological modifier. However, several questions were raised whether or not $\mathrm{BC}$ provokes immune response against itself. For this purpose, passive hemagglutination was performed and negative results were obtained. Our results are also confirmed by (Langer and Gross, 1974) where they classify cartilage as an "immunoprivileged" tissue (Langer et al., 1976).

\section{Conclusion}

The direct anti-tumor activity of BC on tumor cells seems to be through inducing apoptosis and this mechanism of action is the same across different species and cell types. Moreover, it appears that BC does not provoke the host immune response against itself.

\section{Acknowledgements}

This study was partially funded by the Lebanese National Council for Scientific Research

\section{Authors' Contributions}

Arax Tanelian: Contributed to the conception and design of this study, acquisition of laboratory data, data analysis and/or interpretation, drafting and /or critical revision of the manuscript and approved this final version.

Alexander M. Abdelnoor: Contributed to the conception and design of this study, drafting and/or critical revision of the manuscript and approved this final version.

\section{Conflict of Interest}

The authors declare that they have no conflict of interests.

\section{References}

Boyden, S.V., 1951. The adsorption of proteins on erythrocytes treated with tannic acid and subsequent hemagglutination by antiprotein sera. J. Exp. Med., 93: $107-120$.

Durie, B.G., B. Soehnlen and J.F. Prudden, 1985. Antitumor activity of bovine cartilage extract (Catrix-S) in the human tumor stem cell assay. J. Biol. Response Mod., 4: 590-595. PMID: 4087032

Folkman, J., E. Merler, C. Abernathy and G. Williams, 1971. Isolation of a tumor factor responsible for angiogenesis. J. Experim. Med., 133: 275-288. PMID: 4332371

Houck, J.C., R.A. Jacob, L. Deangelo and K. Vickers, 1961. The inhibition of inflammation and the acceleration of tissue repair by cartilage powder. Biochem. Res. Laboratory, 51: 632-638. PMID: 14449250

Kuettner, K.E., L. Soble, R.L. Croxen, B. Marczynska and J. Hiti et al., 1977. Tumor cell collagenase and its inhibition by a cartilage-derived protease inhibitor. Science, 196: 653-654. DOI:10.1126/science.193181

Langer, F. and A.E. Gross, 1974. Immunogenicity of allograft articular cartilage. JBJS, 56: 297-304.

Langer, R., H. Brem, K. Falterman, M. Klein and J. Folkman, 1976. Isolations of a cartilage factor that inhibits tumor neovascularization. Science, 193: 70-72. PMID: 935859 
Morell, S.F. and K.T. Daniel, 2014. Nourishing Broth: An Old-Fashioned Remedy for the Modern World. 1st Edn., Grand Central Publishing, New York, ISBN-10: 1455529230, pp: 352.

Murray, J.B., K. Allison, J. Sudhalter and R. Langer, 1986. Purification and partial amino acid sequence of a bovine cartilage-derived collagenase inhibitor. J. Biol. Chem., 261: 4151-4159. PMID: 3005321

Neter, E., O. Westphal, O. Lüderitz and E.A. Gorzynski, 1956. The bacterial hemagglutination test for the demonstration of antibodies to Enterobacteriaceae. Ann. New York Acad. Sci., 66: 141-156.

Rosen, J., W.T. Sherman, J.F. Prudden and J.G. Thorbecke, 1998. Immunoregulatory effects of catrix. J. Biol. Response Mod., 7: 498-512. PMID: 2846789

Prudden, J.F., M.L. Teneick and D. Svahn, 1964. Acceleration of wound healing in various species by parenteral injection of saline extract of cartilage. J. Surg. Res., 4: 143-144.

Prudden, J.F., 1964. Wound healing produced by cartilage preparations. Arch. Surg., 89: 1046-1059.

Prudden, J.F. and J. Allen, 1965. The clinical acceleration of healing with a cartilage preparation; A controlled study. JAMA, 192: 352-356. PMID: 14282500
Prudden J.F., 1985. The treatment of human cancer with agents prepared from bovine cartilage. J. Biol. Response Modifiers, 4: 551-84.

Prudden, J.F., G. Nishihara and L. Baker, 1975. The acceleration of wound healing with cartilage I. Surg. Gyn. Obs. 105: 283-286. PMID: 13467657

Prudden, J.F., I. Takayuki and L. Campo, 1962. Subcutaneous cartilage pellets: Their effect on wound Tensile Strength. Arch. Surg., 85: 245-246. DOI: 10.1001/archsurg.1962.01310020075016

Prudden, J.F., G. Othmar and B. Allen, 1962. The acceleration of wound healing use of parenteral injections of a saline cartilage extract, with a note on the evaluation of electrophoretically separated fractions of the extract by tissue culture. Arch. Surg., 86: 157-161.

DOI: 10.1001/archsurg.1963.01310070159020

TakayukI, I., 1960. The "cartilage effect" on healing wounds. Arch. Surg., 124: 432-434.

Tanelian, A., D. Jaber, N. Al Akl and A. Abdelnoor, 2016. The effect of bovine cartilage on the growth of mouse B16F10 melanoma cells in vitro and in vivo. Am. J. Immunol., 12: 69.76. DOI: 10.3844/ajisp.2016.69.76 